\title{
The integrated curriculum, university teacher identity and teaching culture: the effects of an interdisciplinary activity
}

\author{
Israel Alonso Sáez ${ }^{1 *}\left(\mathbb{0}\right.$, Naiara Berasategi Sancho² ${ }^{\circledR}$ \\ ${ }^{1}$ Escuela Universitaria de Magisterio de Bilbao, Universidad del País Vasco, España \{lsrael.alonso@ehu.eus\} \\ Escuela Universitaria de Magisterio de Bilbao, Universidad del País Vasco, España \\ \{naiara.berasategi@ehu.eus\}
}

Received on 10 February 2017; revised on 29 March 2017; accepted on 14 April 2017; published on 15 July 2017

DOI: 10.7821/naer.2017.7.235

(c) BY-NC-ND

\begin{abstract}
The results of an investigative process are reported that centre on the impact that modular curricular organization and its interdisciplinary activity are having on the teaching culture in the Degree in Social Education at the University of the Basque Country (UPV/ $\mathrm{EHU}$ ). This understanding of the curriculum is a seminal change for teaching staff and affects their professional identity by encouraging co-responsibility throughout the process. Communicative methodology is employed, which assists in the integration of the people in the investigation, so that they form part of the process of study under equal terms. The production of data was done through in-depth interviews, discussion groups, and documental analysis. The Interdisciplinary Activity Module (IAM) was developed in small groups, of 12-15 individuals, through active methodologies, and the university teachers needed to incorporate it into their discourse and relations with other colleagues and with their students. The results show that an integrated curriculum provides a worthwhile training opportunity to achieve learning of greater significance and depth, and that it happens through changes in their ways of relating and acting as teachers.
\end{abstract}

KEYWORDS: HIGHER EDUCATION, INTERDISCIPLINARY, TEACHING IDENTITY, TEACHING CULTURE

\section{INTRODUCTION}

The design and implementation of the interdisciplinary curriculum in the Degree in Social Education of the UPV/EHU [University of the Basque Country] is an attempt to adapt to the requirements of the European Area for Higher Education (EHEA), as well as being the result of reflection on the need to move towards an integrated curriculum (Elejalde \& Pereira, 2014). It takes the form of a modular design that is constructed with the following keys: a) to manage to generate greater integration of knowledge, progressing towards an integrated curriculum (Knight, Lattuca, \& Kimball, 2013; Pozuelos, Rodriguez, \& Travé, 2012; Toassi \& Lewgoy, 2016), given that knowledge in the real world is holistic, and an integrated approach ensures a higher level of involvement and motivation among students following scientific courses (Arandia \& Fernández, 2012; Knight et al., 2013); and, b) the development of collaborative work between teaching teams (Arandia \&

\footnotetext{
*To whom correspondence should be addressed: Escuela de Magisterio de Bilbao (UPV/EHU) Leioa. 48940

Bizkaia (Spain)
}

Fernández, 2012; Goméz, Escofet, \& Freixa, 2014). The proposal related to the Degree in Social Education arises in this context and draws from experiences with excellent results in Higher Education (HE) at an international level, based on an integrated curriculum and on the development of competences related to both professional practice and working life (Branda, 2008; Collard, Brédart, \& Bourguignon, 2016; Knight et al., 2013; Mullan, Weston, Rich, \& McLennan, 2014; Savin-Baden, 2007; Tierz \& Biedermann, 2015).

Both in the process of the EHEA (Rodicio, 2010) and in the international literature (Biggs, 2006), changes are also proclaimed in in the role of the teacher and in the methodology to be applied to the current university setting. An emphasis in various studies has been placed on a necessary transformation of teacher identity in the society of knowledge; this is the shift from the role and the identity of the expert to another one of animator and facilitator of student learning. The role of the teacher changes completely; from one of a communicator of knowledge to the students, to a mediator in the construction of their own self-knowledge (Bozu \& Canto, 2009; Huber, 2008; Peters, 2008). From a model of teaching characterized by uni-directional and expositive approaches in which the leading player is the teacher, to one of educational exchange, of a multidirectional nature, in which student and teacher converse and act as narrators of the progress that takes place in educational scenarios (Alonso \& Arandia, 2014).

Table 1. Transformations in the identity of the teacher and teaching culture in the knowledge society

Transformations in the identity of the professional university teacher

\begin{tabular}{ll}
\hline From the teacher to the expert & $\begin{array}{l}\text { To animator and facilitator of } \\
\text { learning }\end{array}$ \\
\hline $\begin{array}{l}\text { From teacher as a communicator } \\
\text { of knowledge }\end{array}$ & $\begin{array}{l}\text { To mediator in the construction } \\
\text { of knowledge among students }\end{array}$ \\
\hline From specialist in one subject & $\begin{array}{l}\text { To contributor to scientific } \\
\text { knowledge possessing teaching } \\
\text { skills that stimulate student } \\
\text { learning }\end{array}$ \\
\hline $\begin{array}{l}\text { From being the centre or focus } \\
\text { of attention }\end{array}$ & $\begin{array}{l}\text { To playing a decisive role, trans- } \\
\text { ferring the focus to students and } \\
\text { their learning process }\end{array}$ \\
\hline
\end{tabular}


Transformations in teaching methodology

\begin{tabular}{ll}
\hline $\begin{array}{l}\text { From an unidirectional and } \\
\text { expositive model of teaching }\end{array}$ & $\begin{array}{l}\text { To an educational exchange of a } \\
\text { multidirectional nature based on } \\
\text { dialogue }\end{array}$ \\
\hline $\begin{array}{l}\text { From a theory-based methodo- } \\
\text { logy }\end{array}$ & $\begin{array}{l}\text { To the development of com- } \\
\text { petences related to significant } \\
\text { situations }\end{array}$ \\
\hline $\begin{array}{l}\text { From a methodology in which } \\
\text { the central role was based on } \\
\text { lecturing }\end{array}$ & $\begin{array}{l}\text { To a methodology in which } \\
\text { different strategies are based on } \\
\text { lecturing, practices and projects }\end{array}$ \\
\hline $\begin{array}{l}\text { From a methodology in which } \\
\text { the contents formed the centre }\end{array}$ & $\begin{array}{l}\text { To the development of attitudes, } \\
\text { procedures and growth. Together } \\
\text { with the contents, significant } \\
\text { emotions and actions also appear }\end{array}$ \\
\hline Transformations in teaching culture \\
\hline $\begin{array}{l}\text { From a division between } \\
\text { institutional management }\end{array}$ & $\begin{array}{l}\text { To a culture based on coordina- } \\
\text { tion and shared responsibility }\end{array}$ \\
\hline $\begin{array}{l}\text { To a culture of participation } \\
\text { aith the teacher as an active } \\
\text { innovation }\end{array}$ \\
\hline
\end{tabular}

Source: Alonso (2015)

In the above table, it may be appreciated that this change that the EHAE proposes, not only has an impact on the life of each teacher and subject, but also on the transition towards a more collaborative teaching culture. Reflection and the implementation of the EHEA on each degree course is encouraged to come from joint reflection among all the teachers and not in an individual way in each of the subjects (Perez-Cabani, Juando, \& Palma, 2014; Rué \& Lodeiro, 2010; Terrón, Blanco, Berenguer, \& Learreta, 2007). In short, so that collaboration and team work with other teachers play a central role (Gómez, Escofet, \& Freixa, 2014; Heinric, 2015; Kennelly \& McCormack, 2015). To do so, the organization of transversal teams for innovation is necessary, within departments and different subject modules on the Degree course. There have been several such initiatives, and the literature on them is not lacking, demonstrating the benefits and potentialities of this new way of working (Mauri, Clara, Ginesta \& Colomina, 2013; Pérez-Cabani, Juando, \& Palma, 2014; Rué \& Lodeiro, 2010; Velasco, Rodriguez, \& Terrón, 2012;), as well as the difficulties and the necessity of advancing along this road to cultural change (Martínez et al., 2010; Rué \& Lodeiro, 2010).

All of the above amounts to a change in academic identity, in a complex process in which different factors interact such as representations, knowledge, values and interaction (Alonso, Lobato, \& Arandia, 2015). A change in the identity of the teacher is at the heart of educational innovation; as Monereo and Pozo (2011) have proposed, if teachers will not change, it will be difficult for these innovations to meet with success. This identity is in turn transformed in a teaching context and culture that influences and is influenced by it. The new culture that is generated (Sutherland, \& Taylor, 2011) is also vital in any educational innovation, responding to a series of decisions on the part of the members that constitute it (Pearson, 2010). In these decisions, not only are the circumstances and the rules of external change important (Pearson, 1993) as in this case of the EHEA, but the interpretations of them and the decisions that are taken in the groups that are involved, which makes this process so unique (Witte, Van der Wende, \& Huisman, 2008). In the case under study, the set of teachers participating in a Degree course design and form part of a sea-change in the curriculum that calls into question their identity as teachers and the teaching culture in which they have socialized.

To do so, as may be appreciated in the case study, the benefits but also the difficulties of collaborating with the other teachers who constitute the team that plans, carries out and evaluates the IAM is also important (Heinrich, 2015).

The development of this framework was set in motion in the academic year 2010/11. Its novelties consist of its modular structure, an Interdisciplinary Activity Module (IAM), the Degree teaching team, formed of the degree course coordinator and the coordinators of each module (Alonso, Arandia, \& Beloki, 2017), and the Academic Awards Committee (Aranida, Alonso, \& Cabo, 2016). All these aspects reflect the fabric of curricular innovation that will be implemented and the identity and cultural changes that are encouraged. In this work, we will centre on two of them that are described below:

Modular structure. Teachers participate in the development, planning and evaluation of the modules, taking responsibility for interdisciplinarity in the development of competences and achieving them in relation to the modules. These modules organize knowledge around problematic core themes that function as a single object of knowledge throughout the whole learning-teaching process that takes place in each one of them (Rekalde, Martinez, \& Marko, 2012). Each core theme, in turn, responds to a question: where, who, why, and for what, what does it do, meaning, how, action-reflection. Each question introduces the profession to us, its modes of operation and brings us closer to the analysis of socio-educational problems and the comprehension of educational situations that one might find in professional life. The subject matter found in each module is organized in accordance with its relevance to the knowledge of each one of the questions or central core problems (Arandia, Cruz, Alonso, \& Fernández, 2014; Arandia \& Fernández, 2012).

(1) The Interdisciplinary Activity Module (IAM). In each module there is an IAM found in all the subjects, which represents $15 \%$ of their teaching load. The teaching staff manages each module in an inter-disciplinary way. The objective of the IAM is to prompt the completion of a particular piece of work through student collaboration, reflection and inquiry. To do so, students are set a task relating to a professional global situation that leads them to propose questions, to search for information through documentary and personal sources, data analysis and so on, so that they may construct educational reasoning. This task concludes with the written preparation and oral public presentation of a report, prepared in collaboration as part of a team. The training modality in which this integral task is developed in each module is the seminar that is formed of around twelve students and a teacher, acting as a facilitator of the learning process, supporting students by expounding questions, contrasting what is known and driving profound learning. IAM is approached by employing what are referred to as "active" methodologies that direct the learning by students of these self-directive keys; among others, use is made of Project-based Learning, Cooperative Learning, Problem-based Learning, processes of reflection-action along the lines of Research-Action and Learning-Service (Arandia et al., 2014).

(2) With this background framework, the objective of this research is to determine the impact that the modular organization of the curriculum and its interdisciplinary activity 
is having on the identities and on the teaching culture of the Degree in Social Education (UPV/EHU).

With this background framework, the objective of this research is to determine the impact that the modular organization of the curriculum and its interdisciplinary activity is having on the identities and on the teaching culture of the Degree in Social Education (UPV/EHU).

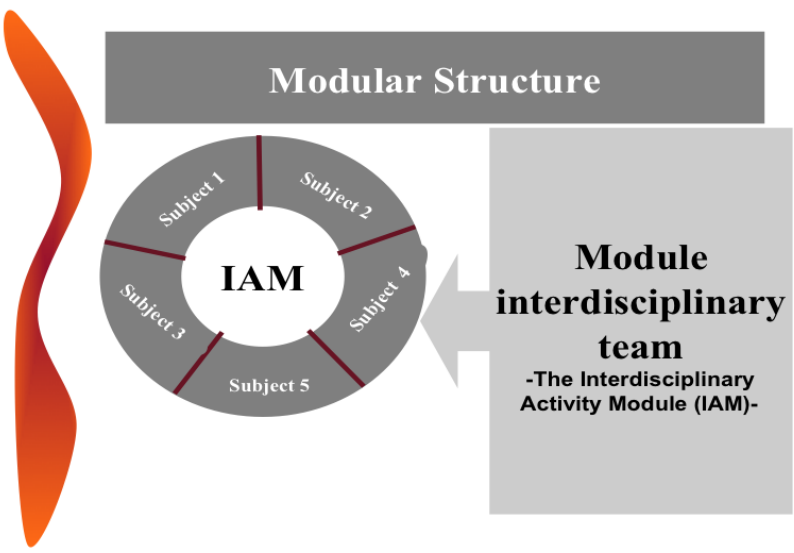

Figure 1. Structure of the module. Source: Primary Education Teacher Training School, Bilbao (2015)

\section{METHODOLOGY}

The methodology of this work, from a qualitative perspective (Denzin, 2012; Tracy, 2011), is communicative, which means that the people in the investigation participate in the process under equal terms (Casamitjana, Puigvert, Soler, \& Tortajada, 2000). The incorporation of these voices, in this case the voices of teachers, contributes to the dependence of the meanings that are construed on the interactions that occur in a context of dialogue upon equal terms, based on reflection, self-reflection, and intersubjectivity (Gómez, Puigvert, \& Flecha, 2011). The methodology assumes these premises and depends on communicative organization throughout the whole process, during which an assessment committee, formed of the teachers of the degree, was set up. This case study was carried out in different phases between January 2013 and July 2015.

\subsection{Sample and participants}

The sample for this study was composed of teachers and students in the case study and by its animators-promoters. In total, the sample consisted of 44 people, segmentation of which was based on the following criteria:

(1) 3 Managers/Coordinators in the organization: Director of the centre, Head of studies and Coordinator of the degree course. These people participated in in-depth interviews.

(2) 28 Teachers. All the teachers in the study (approximately 40) were contacted, of whom ten participated in the indepth interviews, nine in the communicative groups, five in the assessment council and nine in the observation of participants.

(3) 10 students from the third course of the Degree in Social Education. The students who had formed part of the discussion group were contacted. An explanation was given to the delegates, to the student representative on the Degree Committee and more widely in the classroom to all students.

\subsection{Techniques for producing the data}

The data production techniques in use were:

Documental analysis. The study of documentation relating to the design and implementation of the IAM (acts and documents of the design process, records of module evaluations and so on)

In-depth interview. 10 semi-structured in-depth interviews were completed. Each interview followed a process of preparation (choice of interviewees, contacts and preparation of an interview script), interview transcription and its verification by interviewees. The duration of the interview was 90 minutes.

Communicative observation. Throughout the research, communicative observation techniques were employed (Flecha, Vargas, \& Dávila, 2012) participating in two meetings as an external observer: A) A two-day meeting of the module coordinators and two external people; B) Evaluation meeting of one complete day of analysis, in which coordinators, management posts, teachers and students all participated. Notes were taken at both meetings that were subsequently checked with participants in those working contexts.

Communicative group discussion. Two communicative group discussions were organized: with ten students from the case study and with a further 10 male and female students.

Finally, the communicative organization of the investigation was guaranteed through the creation of an assessment council (Flecha et al., 2012) composed of five teachers involved in the case study, This council met at two points in time (half way through and at the end of the process) to discuss the analysis and the results and to be able to integrate it into the definitive research report.

A characterization of the teachers who participated in the different data-collection techniques is shown in the following tables.

In the first round of interviews, 10 teachers were invited in accordance with the following criteria: a) they were active in the different Departments in which teaching on the Degree course was imparted; b) they were teaching on the different (four-month) modules; and, c) they presented different career paths and levels of involvement in the design of the Degree (with a minimum of three years of teaching experience). The characteristics of this group of teachers are shown in Table 2.

The subject-module coordinators and the staff took part in the two sessions that one of the authors attended as a participating observer. The characteristics of the teachers who participated in these two meetings are shown in Table 3.

In the second phase, an invitation was shared with the other teachers who had been working for over two years on the Degree course and had not participated in the aforementioned techniques, a total of 19 teachers, of whom 9 participated in the Communicative Discussion Group. Their characteristics are shown in Table 4.

The participation of 11 students of both sexes was divided into a communicative group with six in one group and another six in the participant observation sessions. A first group were studying in the third year of their degree course and the other eight were from various years following subjects in Castilian Spanish and Euskera.

Finally, five teachers participated in the evaluation committee. Three women and one man from different departments, with differing positions and experience on the Degree in Social Education of Bilbao and one teacher on the Degree of Social Education of San Sebastian at the Faculty of Philosophy and Educational Sciences. 
Table 2. Characteristics of the participants in the in-depth interview

\begin{tabular}{|c|c|c|c|c|c|}
\hline Teacher & Sex & Contract & Phd/ & Department & Experience \\
\hline 1 & Woman & Permanent & Yes & MIDE & Over 15 years since Teaching Dip. \\
\hline 2 & Woman & Permanent & Yes & MIDE & Over 15 years since Teaching Dip. \\
\hline 3 & Woman & Permanent & No & DOE & Over 15 years since Teaching Dip. \\
\hline 4 & Man & Permanent & Yes & Theory \& History & Over 15 years since Teaching Dip. \\
\hline 5 & Woman & Permanent & No & Sociology & Over 15 years since Teaching Dip. \\
\hline 6 & Woman & Temporary & Yes & Educational Psychology & Less than 5 years as a teacher. \\
\hline 7 & Woman & Permanent & Yes & Dept. of Education & Over 15 years in teacher teaching. \\
\hline 8 & Woman & Permanent & Yes & Theory of History & Over 15 years in teacher training. \\
\hline 9 & Woman & Permanent & No & $\begin{array}{l}\text { Educational Sciences } \\
\text { Didactics }\end{array}$ & Over 15 years since Teaching Dip. \\
\hline 10 & Woman & Permanent & Yes & Language Teaching & Over 15 years since Teaching Dip. \\
\hline
\end{tabular}

Table 3. Characteristics of participants in communicative observation

\begin{tabular}{llllll}
\hline Teacher & Sex & Contract & Phd & Department & \multicolumn{1}{c}{ Experience } \\
\hline 1 & Woman & Permanent & Yes & MIDE & Over 15 years since Teaching Dip. \\
2 & Woman & Permanent & Yes & MIDE & Over 15 years since Teaching Dip. \\
11 & Woman & Permanent & Yes & DOE & Over 15 years since Teaching Dip. \\
12 & Man & Permanent & Yes & Social Psychology & Over 5 years as a teacher, qualified with Diploma. \\
13 & Woman & Permanent & Yes & Sociology & Over 15 years since Teaching Dip. \\
14 & Woman & Permanent & Yes & DOE & Over 15 years in teacher training. \\
15 & Woman & Permanent & Yes & Theory of History & Over 15 years in teacher training. \\
16 & Man & Permanent & Yes & Theory of History & Over 15 years in teacher training. \\
17 & Woman & Permanent & Yes & DOE & Over 15 years since Teaching Dip. \\
\hline
\end{tabular}

Source: Authors.

Table 4. Characteristics of participants in the communicative discussion group

\begin{tabular}{llllll}
\hline Teacher & Sex & \multicolumn{1}{c}{ Contract } & Phd & \multicolumn{1}{c}{ Department } & \multicolumn{1}{c}{ Experience } \\
\hline 18 & Mujer & Woman & Yes & Educational Psychology & Over 5 years as a teacher, qualified with Diploma. \\
19 & Mujer & Woman & No & Educational Psychology & Over 15 years since Teaching Dip. \\
20 & Mujer & Woman & No & Theory of History & Over 5 years as a teacher. \\
21 & Mujer & Woman & Yes & MIDE & Over 5 years as a teacher, qualified with Diploma. \\
22 & Hombre & Man & No & MIDE & Over 15 years since Teaching Dip. \\
23 & Mujer & Woman & No & DOE & Over 5 years as a teacher, qualified with Diploma. \\
24 & Mujer & Woman & Yes & DOE & Over 5 years as a teacher, qualified with Diploma. \\
25 & Hombre & Man & Yes & Educational Psychology & Over 15 years in teacher training. \\
26 & Mujer & Woman & No & DOE & Less than 5 years as a teacher. \\
\hline
\end{tabular}

Source: Authors. 
As previously mentioned, 31 different teachers (two of whom participated in two techniques), almost three quarters of all teachers on the Degree course, were involved in some of the data-collection techniques.

\subsection{Data analysis}

All the data was transcribed, registered and coded using the NVivo 10 qualitative analysis programme. Throughout the process, new data resources were included such as field notes, memorandums, among others. On the basis of the earlier steps, an analysis was conducted with the NVIVO programme, focusing attention on those themes that were emerging in a natural way. This first coding state permitted a preliminary inductive categorization to move on to reorganization of the data, in a second stage, yielding the definitive categorical system and, finally, regrouping all the related data.

\section{RESULTS}

One of the core functions of the teaching teams on each module is the design, the implementation and the evaluation of the IAM. This new way of understanding the curriculum, incorporating interdisciplinarity, is a sea-change for teachers and it affects their professional identity by making them co-responsible throughout the process. As has been seen, the IAM is developed in small groups, of around 12-15 individuals, through active methodologies, and academic professionals have to incorporate it into their way of understanding and relating to the other colleagues and with the students.

\subsection{Positive and transformational aspects of the interdisciplinary activity module in both teacher identity and teaching culture}

The following aspects may be highlighted in the evaluation undertaken by students and teaching staff of the impact that the IAM is having on the student-learning process and on the new role of teachers: a) It is allowing the integration of different modules; b) As the profile of their competences develop, students see the processes in a clearer manner; c) Tutoring processes are closer and generate dynamics that are impossible to achieve with larger groups. Student satisfaction is high and the consideration given by many teachers to what they teach makes it possible for learning to occur in a more meaningful and independent manner; and, d) change and progress in the training of students.

In the following testimony, it may be appreciated how working with a task such as the IAM influences the student training process:

It is rewarding. For example, I'm on the Social Education Degree, I give classes in the first and in the third year, in module 1 and in module 6; this is the first year that I have worked on module 6 . Well, to see the change in students has been thrilling. For example, in the work on IAM, the degree of independence that they have gained, when doing the IAM, from module 6 in relation to the first [module] where you almost have to get hold of them and lift up their arm... "come on, give me the first draft, come on..." You sit down with them, you almost write it,... "Try to see how you do it..." A complete change. (FC1ED10)
Likewise, it was observed that it was not easy to move from the theory on modular and interdisciplinary themes to its application in teaching practice. One teacher pointed out that:

...the theme of the IAM, the idea seems very good to me, but the difficult thing is to put it into practice and to see when they finally achieve the objective and the competences, but (...) even then, each subject goes where it will, it's a bit compartmentalized, and nevertheless it can give an idea of greater globality to propose the module in relation with... and this does seem to me... to adapt the subject to the IAM and to give it another perspective, and then if you manage to do that, I still haven't done it (...) (FC1ED6).

As happens in all deep educational innovation, difficulties and dangers arise that have to be solved step by step. The most persistent are precisely those linked to the change in teacher identity, with regard to the role, the evaluation, the knowledge, the necessary know-how, and teamwork.

\subsection{Difficulties, dangers and challenges of the Interdisciplinary Activity Module}

The two difficulties of greatest importance were:

(1) The lack of education and competences for tutoring in these processes. New needs emerged in the tutoring process: reading the dynamics of the group, resolution of conflicts, driving autonomous learning... Regarding these needs, tutors are not always in possession of the tools to confront them, or, are not sufficiently perceptive to have them available and/or to master them. This leads to a degree of collapse of the certainties with regard to their identity as teachers. We should keep in mind that teachers have to cross a security zone, to arrive at another in which they have to integrate new forms of understanding and of practicing teaching. Managing to do so requires preparation, dialogue and reflection in teaching teams.

(2) The way of setting out the evaluation with these new methodological proposals (Paricio, 2010). In the words of one teacher:

We don't know about evaluation, evaluating teamwork, and I think that I can say so, because it's a point that comes up continuously in the teaching teams that I've been in. We don't discriminate... Take care about the degree of involvement of somebody, don't let them get away, don't put up with parasites within the groups... that sort of thing (FC1ED10).

Accepting and facing up to this challenge of new forms of evaluation has led to setting up strategies that go deeper into a teacher identity that is marked by collaboration and greater interaction and closeness with students. A strategic solution found in different teaching teams is pair correction. But it is still insufficient.

The topic of correcting one another cropped up, I don't think that's enough, because what I want to know is whether we're doing the tutoring well, how to achieve IAM or the strategies to work the IAM, how we are doing jointly, and if they suggest this feed-back... but we are not at those levels, of course that's the task, it takes time, but it's necessary ...(FC1ED2). 
Some teachers go further and point to the need for greater coordination and coherence in the job, both in the definition of the evaluation criteria and in the orientation given in the processes of tutoring to undertake the evaluation fairly and equitably.

On this path, the danger of bureaucratization and routinization of the work by the students is flagged up. When that happens, the most creative and open learning that the IAM aspires to promote is at risk. The tutor has to be attentive and to carry out conscientious follow up, so as not to engender automatization in learning. The following teacher describes it in the following terms,

I also have to say that I see that they have made it a little bureaucratic... That part left me, that's to say... like in the first IAM, they get scared off, and so do we, the teachers in first place, as you look after it, you really get on top of it, you do many more tutoring sessions than are expected, because-... because otherwise you lose the students... So far so good, this year the IAM has been much more comfortable... but, because they know it all, (...) (FC1ED10).

Although subsequently, this same teacher expressed how all of this depends a lot on the diversity of the work groups that were formed and on the time when they meet.

They shrug off their independence, they say "Look, tell me clearly what it is that you are going to mark and what you are going to take into account; we'll get down to it and do it"... But well, then there are always exceptions. I had a group this year, in the IAM, that in addition I think was a group that had very shaky self-esteem, (...) a difficult group... and well, at the beginning they had an attitude in the IAM, "Well, you tell us, how do we do..." And I say... and they had done a good SWOT analysis, the analysis of weaknesses and strengths of the educational association that works with older people, which was very well done. I tell them, "Well, take the bull by the horns, if you think that the problem of this association is that it isn't there, that it has no spatial or geographic location in a city, and it's not focusing on a particular reality, and therefore... It's integrated in institutions, but it is not working on the group, well say as much to that association"... and well, they rose to the challenge (FC1ED10).

Given the consideration of IAM as a learning situation of great formative potential, some speak of certain challenges and proposals to be able to face up to the difficulties and dangers that have been mentioned. These are:

Joint reflection and organization. It is a question of facilitating spaces for dialogue, contrast, learning and improvement for teachers, where each teacher expresses how to approach tutoring, sets out reflections on the potential aspects and the limits; and establishes patterns among them all for improvement.

Linking each subject to the IAM process. These linkages once again require reinforcement through teamwork that, in turn, supports the change in identity and the cultural changes that are forming.

Institutional support for these new forms of teaching requested by teachers and students. This support is the global indicator that all processes of cultural change and change of identity require structural and administrative transformations that channel them and lend them support. Their absence can lead to a clear involution of the process, risking everything that has been gained up until that time; caring for it is therefore necessary.
Finally, it is important to observe that all the actions pointed out in the teaching modes, in the use of different methodologies that require high levels of inquiry and reflexion, implies greater openness to dialogue with students and also an impact on their learning. From the different evaluations of the IAM that have been carried out, we may highlight some aspects that will be repeated, which are: a) greater motivation than with other teaching methods; b) a positive evaluation of learning that is based on real professional situations with which the student has to work independently; and, c) high development of competences connected to team work and inter-personal relations. The testimony of some interviewees, spoke of how students feel when learning and how they see their analysis of educational reality are as follows:

I have had the opportunity of meeting with educators who finished 3 years ago and they left me amazed at the very different learning processes that we have and I told them about projects and you realize what a gift the degree was and the process in which we are participating and people have not had spaces like the ones that we are having (...) I'll stay with the foundations that we have (...) and how many teachers have transmitted that responsibility of wishing to give and the effects that it can have on others and to check with our companions and how we can do it with our innermost self (...)".

We have to highlight the capability of the group to act with values, with respect, apart from the teaching that we have. Somebody in the class said to me that one day we arrive looking through a very small hole that has been widening and we increasingly see the reality and we are growing, working and something has come out shining and above the respect, the empathy, the awareness and we have all benefitted from the difficulties".

\section{DISCUSSION}

It is important to advance towards a teacher identity and a teaching culture that assumes interdisciplinarity in the university curriculum (Monereo \& Pozo, 2003), so that this is not simply a puzzle of content and knowledge, the global reach of which nobody or almost nobody knows. The IAM developed in the Degree in Social Education is a worthwhile step in that direction, given that it confronts students with professional situations in the face of which they have to develop critical judgement, take decisions that are reasoned and upheld in educational terms and they even, in some cases, have to draft a proposed course of action that calls for the activation of different knowledge learnt in the educational process (Arandia et al., 2014). In this way, the contributions of students and teachers with regard to the process through which they have lived highlight that an integrated curriculum provides an opportunity to achieve more meaningful and deeper learning levels. Studies developed in other academic contexts also confirm that the spaces and models for the treatment of learning help in an integral way to make sense of learning and to motivate students more (Savin-Baden, 2007; Tierz \& Biedermann, 2015). Likewise, the educational and interdisciplinary approaches stimulate innovation with greater efficacy than educational programmes based on a discipline (Knight et al., 2013). Moreover, those who would defend this type of programme show that an educational proposal of an interdisciplinary nature for a Degree prepares students better for the job market and the participation of citizens, facilitating the development of their capability for the solution of problems 
and capabilities of critical thought (Knight et al., 2013; Newell \& Reilly, 1999).

This approach requires teachers to move from a role and an identity of expert to another of guide and facilitator of student learning (Biggs \& Tang, 2008; Bozu \& Canto, 2009). As may be gleaned from this investigation, it is no easy task. It takes time, training and learning spaces to accept this form of being a university teacher in a natural way.

\section{CONCLUSIONS}

The analysis of the case study that proposes how to advance towards a new identity for the teacher and a teaching culture that incorporates interdisciplinarity in the university curriculum is of importance (Monereo \& Pozo, 2003), so that it will not merely be a puzzle of contents and knowledge, the globality of which nobody or almost nobody is aware. It is a sea-change that, as has been shown in this case study, is of greater depth and impact when applied to the whole degree course and not only through some teachers. It involves changes in the way teachers understand themselves, and acceptance of the interdisciplinarity of one part of the curriculum, with all of what that entails for cooperation and collaboration with other teachers. As reflected in this study, this change is no easy task. It requires time, training and learning spaces, to accept this new form of being a teacher at university in a natural way and to understand the curriculum accordingly.

\section{FUNDING}

This article is linked to the line of Active Education of the consolidated research group Ikasgura (GIU 14/08) of the University of Basque Country

\section{REFERENCES}

Alonso, I. (2015) Cambios en las identidades y culturas docentes en procesos de innovación curricular en la Educación Superior. Estudio de un caso (Doctoral dissertation). Universidad del País Vasco/ Euskal Herriko Unibertsitatea.

Alonso, I., \& Arandia, M. (2014) Aprender creando: "Factoría Creativa" en las aulas universitarias. REDU. Revista de Docencia Universitaria, 12(1), 443-468.

Alonso, I., Arandia, M., \& Beloki, N. (2017). Hacia un liderazgo distribuído en los grados universitarios. In Capdevilla, D. (Ed.), Trabajos docentes para una universidad de calidad. Madrid: Mcgraw-Hill.

Alonso, I., Lobato, C., \& Arandia, M. (2015). A Professional Teaching Identity as Key to Change in Higher Education. Opción, 31(5), 51-71.

Arandia, M., Alonso, I., \& Cabo, A. (2016). The Professional and the Academic World Learning Together in Higher Education. Opción, 32(7), 118-137.

Arandia, M., Cruz, E., Alonso, I., \& Fernández, B. (2014). La incorporación de la voz del alumnado en el desarrollo de una estructura curricular modular. La experiencia del grado de educación social en la UPV-EHU. Tendencias Pedagógicas, $23,215-236$.

Arandia, M., \& Fernandez, I. (2012) ¿Es posible un curriculum más allá de las asignaturas? Diseño y práctica del grado de Educación Social en la Universidad del País Vasco. REDU. Revista de Docencia Universitaria, 10(3), 99-123.

Biggs, J. B. (2006). Calidad del aprendizaje universitario. Madrid: Narcea Ediciones.

Biggs, J., \& Tang, C. (2008). Teaching for quality in higher education. Berkshire: Mcgraw-Hill Education.

Bozu, Z., \& Canto, P. J. (2009) El profesorado universitario en la sociedad del conocimiento: Competencias profesionales docentes. Revista De Formación e Innovación Educativa Universitaria, 2(2), 221-231.

Branda, L. (2008) El aprendizaje basado en problemas. El resplandor tan brillante de otros tiempos. In U. Araujo, \& G. Sastre (Eds), El aprendizaje basado en problemas. Una nueva perspectiva en la enseñanza en la universidad (pp. 2325). Barcelona: Gedisa.

Casmitjana, M., Puigvert, L., Soler, M., \& Torjada, I. (2000) Investigar y tranformar: CREA, Centro de Investigación Social y Educación. Cultura y Educación, 12(12), 117-128. doi:10.1174/113564000753837232

Collard, A., Brédart, S., \& Bourguignon, J. P. (2016). Context impact of clinical scenario on knowledge transfer and reasoning capacity in a medical problem-based learning curriculum. Higher Education Research \& Development, 35(2), 242253. doi: $10.1080 / 07294360.2015 .1087383$

Denzin, N. K. (2012) Triangulion 2.0. Journal of Mixed Methods Research, 6(2), 80-88. doi:10.1177/1558689812437186

Elejalde, M. J., \& Pereira, J. A. (Eds.) (2014). Los grados universitarios: posibilidades y caminos de innovación. Bilbao: UPV/EHU.

Flecha, R., Vargas, J., \& Davila, A. (2012). Metodología comunicativa crítica en la investigación en ciencias sociales: La investigación WORKALÓ. Lan Harremanak. Revista De Relaciones Laborales, 11, 21-33.

Gómez, M., Escofet, A., \& Freixa, M. (2014). The teaching staff in higher education eutopia or reality? Revista Española de Pedagogía, 72(259), 509-523.

Gómez, A., Puigvert, L., \& Flecha, R. (2011). Critical communicative methodology: Informing real social transformation through research. Qualitative Inquiry, 17(3): 235-245. doi:10.1177/1077800410397802

Heinrich, E. (2015). Identifying teaching groups as a basis for academic development. Higher Education Research \& Development, 34(5), 899-913. doi:10.108 0/07294360.2015.1011091

Huber, G. L. (2008). Aprendizaje activo y metodologías educativas. Revista de Educación, $\mathrm{N}^{\mathrm{o}}$ Extra, 59-81.

Kennelly, R., \& McCormack, C. (2015). Creating more 'elbow room' for collaborative reflective practice in the competitive, performative culture of today's university. Higher Education Research \& Development, 34(5), 942-956. doi:10.10 80/07294360.2014.911259

Knight, D. B., Lattuca, L. R., \& Kimball, E.W. (2013). Understanding interdisciplinarity: Curricular and organizational features of undergraduate interdiciplinary programs. Innovative Higher Education, 38(2), 143-158. doi:10.1007/s10755012-9232-1

Martínez, I., Arandia, M., del Castillo, L. \& Santamaría, M (2010). El trabajo en equipos como estratégia para la formación. In J. Rué, \& L. Lodeiro (Eds.), Equipos docentes y nuevas identidades académicas (pp. 85-112). Madrid: Narcea.

Monereo, C., \& Pozo, J. I. (2003). La cultura educativa en la universidad: nuevos retos para profesores y alumnos. La universidad ante la nueva cultura educativa. Enseñar y aprender para la autonomía, 15-30.

Monereo, C., \& Pozo, J. I. (2011). La identidad en psicología de la educación. En C. Monereo, \& J. I. Pozo (Coord.), La Identidad en Psicología de la Educación. necesidad, utilidad y limites (pp. 45-56). Madrid: Narcea.

Mullan, J. R., Weston, K. M., Rich, W. C., \& McLennan, P. L. (2014). Investigating the impact of a research-based integrated curriculum on self-perceived research experiences of medical students in community placements: a pre-and post-test analysis of three student cohorts. BMC Medical Education, 14(1), 161. doi:10.1186/1472-6920-14-161

Newell, A., \& Reilly, B. (1999). Rates of Return to Educational Qualifications in the Transitional Economies. Education Economics, 7(1), 67-84. doi:10.1080/09645299900000005

Paricio, J. (2010). El reto de institucionalizar la coordinación e integración docente. In J. Rué, \& L. Lodeiro (Eds.), Equipos docentes y nuevas identidades académi$c a$ (pp. 21-39). Madrid: Narcea.

Pearson, P. (2000). Not just what, but when: Timing and sequence in political processes. Studies in American Political Development, 14, 72-92. doi:10.1017/ S0898588X00003011

Pérez-Cabani, J., Juando., J., \& Palma, M. (2014). La formación del profesorado universitario en los parámetros europeos: afrontar un cambio de estructura, de cultura y de identidad profesional. In C. Monereo (Ed.), Enseñando a enseñar en la universidad. La formación del profesorado basada en incidentes críticos (pp. 45-56). Barcelona: Octaedro/ICE-UB.

Peters, O. (2008). Transformation through open universities. In T. Evans, M. Haughey, \& D. Murphy, International Handbook of Distance Education (pp. 279-298) Bingley: Emerald.

Pierson, P. (1993). When effect becomes cause: Policy feedback and political change. World politics, 45(04), 595-628. doi:10.2307/2950710

Pozuelos, F. J., Rodríguez, P., \& Travé, G. (2012). El enfoque interdisciplinar en la Enseñanza universitaria y aprendizaje basado en la investigación. Un estudio de caso en el marco de formación. Revista de educación, 357, 213-214.

Rekalde, I., Martínez, B., \& Marko, J. (2012). Los proyectos interdisciplinares de módulo: Una experiencia innovadora en el Grado de Educación Social de la UPV/EHU. REDU. Revista de Docencia Universitaria, 10(3), 209-237.

Rodicio, M. L. (2010). La docencia universitaria en el proceso de adaptación a Europa: la percepción de los estudiantes. Enseñanza \& Teaching: Revista interuniversitaria de didáctica, 28, 23-43.

Rué, J., \& Lodeiro, L. (Eds.) (2010). Equipos docentes y nuevas identidades académicas. Madrid: Narcea.

Savin-Baden, M. (2007). Challenging models and perspectives of problem-based learning. In D. Graaff, \& A. Kolmos (Eds.), Management of change: Implementation of problem based and project based learning in engineering (pp. 9-29). Rotterdam/Taipei: Sense Publishers. 
Sutherland, K., \& Taylor, L. (2011). The development of identity, agency and community in the early stages of the academic career. International Journal for Academic Development, 16(3), 183-186. doi:10.1080/1360144X.2011.596698

Terrón, M. J., Blanco, Y., Berenguer, F. J., \& Learreta, B. (2007). La coordinación del profesorado como necesidad en la construcción del EEES: una experiencia en investigación-acción. Cuadernos de innovación educativa en las enseñanzas técnicas universitarias, 1-2, 75-85.

Tierz, A., \& Biedermann, A. M. (2015). Roles and Groups Dynamic as a Systematic Approach to Improve Collaborative Learning in Classroom. Creative Education, 6(19), 2105-2116. doi:10.4236/ce.2015.619214

Toassi, R., \& Lewgoy, B., (2016). Integrated Health Practices I: an innovative experience through inter-curricular integration and interdisciplinarity. Interface-Comunicação, Saúde, Educação, 20(57), 449-461. doi:10.1590/1807-57622015.0123

Tracy, S. (2011). Qualitative research methods: Collecting evidence, crafting analysis, communicating impact. Malden: Wiley.

Velasco, P. J., Rodríguez, R. M., \& Terrón, M. J., (2012). La coordinación del profesorado universitario: un elemento clave para la evaluación por competencias. REDU: Revista de Docencia Universitaria, 10(3), 265.

Witte, J., Van der Wende, M., \& Huisman, J. (2008). Blurring boundaries: How the Bologna process changes the relationship between university and non university higher education in Germany, the Netherlands and France. Studies in Higher Education, 33(3), 217-231. doi:10.1080/03075070802049129

How to cite this article: Alonso, I. J., \& Berasategi, N. (2017). The integrated curriculum, university teacher identity and teaching culture: the effects of an interdisciplinary activity. Journal of New Approaches in Educational Research, 6(2), 127-134. doi: 10.7821/naer.2017.7.235 